\title{
Equatorial Guinea
}

National Cancer Institute

\section{Source}

National Cancer Institute. Equatorial Guinea. NCI Thesaurus. Code C16557.

A country in western Africa, bordering the Gulf of Guinea, between Cameroon and Gabon; composed of a mainland portion and five inhabited islands. 